\title{
T-Cell Differentiation in the Thymus
}

National Cancer Institute

\section{Source}

National Cancer Institute. T-Cell Differentiation in the Thymus. NCI Thesaurus. Code C19317.

The progression of T cell precursors in the thymus through many stages of maturation. These stages include regulated expression of the alpha and beta (or gamma and delta) chains of the T cell receptor, expression of both CD4 and CD8 molecules (double positive stage), down regulation to a single positive stage (CD4 or CD8), as well as allowing those thymocytes to die which are unable to bind to self MHC molecules (death by neglect), selecting those thymocytes with T Cell Receptors that are able to bind to self MHC molecules with moderate affinity (positive selection), and deleting those thymocytes having $\mathrm{T}$ Cell Receptors that bind with high affinity to self MHC (negative selection), before allowing mature $\mathrm{T}$ cells to emigrate to the periphery. 